Justyna Matys

\title{
WPŁYW CZASU NA CELE I FUNKCJE UŻYTKOWANIA WIECZYSTEGO
}

\section{Geneza prawa użytkowania wieczystego w prawie polskim}

Użytkowanie wieczyste jest prawem charakterystycznym dla ustroju socjalistycznego ${ }^{1}$. Mimo przekształcenia gospodarki centralnie planowanej w wolnorynkową instytucja ta przetrwała $\mathrm{w}$ prawie polskim i nadal znajduje zastosowanie w praktyce. W doktrynie podejmowana jest dyskusja co do potrzeby dalszego funkcjonowania użytkowania wieczystego: czy należy pozostawić je jako ,stanowiące sprawne narzędzie gospodarki rynkowej, dostępne dla wszystkich podmiotów na równych zasadach, konkurujące w obrocie z prawem własności ${ }^{2 ”}$ ", dokonać wyłącznie koniecznych modyfikacji ${ }^{3}$, czy może zrezygnować z prawa użytkowania wieczystego, a użytkowników wieczystych uwłaszczyć4

Upływ czasu oraz zmiany ustroju społeczno-gospodarczego wywarły ogromny wpływ na zakres podmiotowy, przedmiotowy, cele i funkcje użytkowania wieczystego. Można postawić tezę, że cele i funkcje użytkowania wieczystego są ściśle powiązane z zakresem podmiotowym i przedmiotowym tego prawa. W zależności od podmiotu, na którego rzecz prawo zostało ustanowione, a także przeznaczenia oddawanych w użytkowanie wieczyste gruntów prawo to spełniać może różne cele. Widoczne jest rozszerzanie zakresu podmiotowego i przedmiotowego prawa wraz

1 Zob. J. Winiarz, (w:), J. Ignatowicz (red.) System prawa cywilnego, t. II, Prawo własności i inne prawa rzeczowe, Wrocław 1977, s. 554.

2 Wyrok TK z dn. 12.4.2000 r., K 8/98, OTK 2000, nr 3, poz. 87.

3 Zob. G. Bieniek, W sprawie przyszłości użytkowania wieczystego, (w:) Ars et usus. Księga pamiątkowa ku czci Sędziego Stanisława Rudnickiego, Warszawa 2005, s. 53 i nast.; A. Cisek, (w:) E. Gniewek (red.), System Prawa Prywatnego, t. IV, Prawo rzeczowe, Warszawa 2007, s. 229; Z. Gawlik, Użytkowanie wieczyste de lege ferenda, (w:) M. Sawczak (red.), Czterdzieści lat Kodeksu cywilnego. Materiały z Ogólnopolskiego Zjazdu Cywilistów w Rzeszowie (8-10.10.2004 r.), Kraków 2006, s. 115; E. Gniewek, O przyszłości użytkowania wieczystego, „Rejent” 1999, nr 2, s. 11 i nast.; E. Gniewek, O przyszłości użytkowania wieczystego - dyskusji ciąg dalszy, „Studia luridica Agraria” 2005, t. 5, s. 49 i nast.; Z. Truszkiewicz, Użytkowanie wieczyste. Zagadnienia konstrukcyjne, Kraków 2006, s. 654 i nast.; C. Woźniak, Użytkowanie wieczyste, Warszawa 2006, s. 255 i nast.

4 Zob. A. Brzozowski, Z problematyki przekształcenia prawa użytkowania wieczystego w prawo własności, ,Zeszyty Prawnicze Uniwersytetu Kardynała Stefana Wyszyńskiego" 2003, nr 3.2, s. 89. 
z upływem czasu, co wpływa na poszerzenie możliwości stosowania użytkowania wieczystego dla różnych celów, nie tylko już związanych z budownictwem mieszkaniowym. Jednak trzeba też zauważyć podejmowane próby przekształcenia tego prawa w prawo własności, co może przemawiać za jego zniesieniem w przyszłym ustawodawstwie.

Obecnie obowiązujące przepisy regulujące prawo użytkowania wieczystego bardzo znacząco różnią się od przepisów ustawy z dnia 14 lipca 1961 r. o gospodarce terenami w miastach i osiedlach ${ }^{5}$, na podstawie których ustawodawca wprowadził do polskiego porządku prawnego to prawo.

Ważnym jest wskazanie, że długo poszukiwano właściwej formy korzystania przez podmioty z gruntów państwowych. Pierwszą instytucją poprzedzającą użytkowanie wieczyste w prawie polskim po II wojnie światowej było prawo zabudowy wprowadzone dekretem z dn. 26 września 1945 r. o prawie zabudowy ${ }^{6}$. Prawo to polegało na tym, że Państwo i związki samorządu terytorialnego, będący właścicielami gruntu, mogły ustanowić na rzecz innej osoby na całości lub części tego gruntu prawo wzniesienia jednego lub większej ilości budynków na czas i za wynagrodzeniem oznaczonymi w umowie. Osoba, która od właściciela gruntu uzyskała prawo zabudowy, nabywała co do budynku prawo własności, a co do gruntu prawo użytkowania. Przełamana tym samym była zasada superficies solo cedit. Prawo to mogło być ustanawiane na czas nie krótszy niż lat 30 i nie dłuższy niż lat 80 z możliwością dalszego przedłużenia, a z upływem czasu, na które było ustanowione, budynek przechodził za wynagrodzeniem ustanowionym w umowie na rzecz właściciela gruntu. Celem wskazanego prawa była wyłącznie zabudowa cudzego gruntu, co podlegało krytyce ${ }^{7}$. Dekret o prawie zabudowy obowiązywał bardzo krótko (ponad rok), został uchylony dekretem prawo rzeczowe ${ }^{8}$, wprowadzającym własność czasową.

Istota własności czasowej z dekretu prawo rzeczowe sprowadzała się do przeniesienia przez Skarb Państwa albo przez związek samorządu terytorialnego lub inną osobę prawną prawa publicznego własności na rzecz osoby fizycznej lub prawnej na wskazany czas wynoszący od 30 do 80 lat z możliwością dalszego przedłużenia. Po jego upływie własność powracała z mocy prawa do poprzedniego właściciela na podstawie ustawowego prawa powrotu, które uważane było za prawo rzeczowe ograniczone (art. 108 prawa rzeczowego). W umowie określano sposób korzystania $\mathrm{z}$ nieruchomości, a gdy miała ona być zabudowana, również $\mathrm{m}$. in. termin rozpoczęcia i zakończenia prac, rodzaj budynku i innych urządzeń. W doktrynie wskazywało się, że pod względem konstrukcji prawnej własność czasowa stanowiła własność podzieloną pod względem czasu i treści. Przeznaczana była głównie na potrzeby

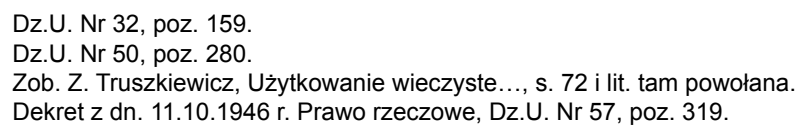


budownictwa mieszkalnego, ale także mogła służyć innym potrzebom społecznym i gospodarczym. Należycie chroniła interesy właściciela czasowego i zbywcy ${ }^{9}$. Jednak w praktyce instytucja własności czasowej nie przyjęła się. Przede wszystkim nie odpowiadała ona podstawowej regule jedności funduszu własności ogólnonarodowej: własność czasowa prowadziła do czasowej reprywatyzacji zasobów państwa ${ }^{10}$. Ponadto określenie „własność czasowa” mogła, zdaniem jej przeciwników, zniechęcać do budowy na gruncie oddanym na własność, skoro po upływie wskazanego okresu własność powracała do zbywcy ${ }^{11}$.

Właściwa forma prawna $\mathrm{z}$ jednej strony musiała odpowiadać ustrojowym zasadom PRL, zaś z drugiej umożliwiać dostarczenie przez państwo gruntów w celu zaspokojenia potrzeb społecznych, w tym potrzeb mieszkaniowych. Ważnym było również, aby instytucja była łatwa do kontrolowania przez państwo. Wobec zarzutów stawianych własności czasowej zostało wprowadzone, dekretem o odstępowaniu przez państwo nieruchomego mienia nierolniczego na cele mieszkaniowe oraz na cele budownictwa mieszkaniowego ${ }^{12}$, prawo użytkowania. Dekretem nie została uchylona własność czasowa, funkcjonowała ona obok użytkowania.

Na podstawie dekretu z 1952 r. przedmiotem odstępowania mogły być położone w miastach i osiedlach o charakterze miejskim: jednorodzinne domy mieszkalne z zabudowaniami gospodarczymi i przylegającymi bezpośrednio podwórzami, ogrodami lub sadami, o ile nie stanowiły nieodłącznej części składowej gospodarstw rolnych lub działki ziemi o powierzchni nieprzekraczającej $1.000 \mathrm{~m}^{2}$ przeznaczone na cele indywidualnego budownictwa domów jednorodzinnych i położone na terenach w tym celu wydzielonych. Zgodnie z art. 3 dekretu budynki mogły być odstępowane $\mathrm{w}$ trybie dzierżawy lub $\mathrm{w}$ wyjątkowych przypadkach w drodze sprzedaży z jednoczesnym odpłatnym ustanowieniem użytkowania jako prawa wieczystego na gruncie, na którym budynki się znajdowały. Odstępowanie działek gruntu następowało $\mathrm{w}$ trybie ustanowienia odpłatnego użytkowania jako prawa wieczystego z zastrzeżeniem w umowie przeznaczenia działki pod budowę domu jednorodzinnego na warunkach ustalonych dla indywidualnego budownictwa mieszkaniowego.

Umowa o odstapienie wymagała formy pisemnej. Obowiązkiem użytkownika było uiszczanie czynszu z tytułu korzystania $\mathrm{z}$ gruntu państwowego w wysokości $1 \%$ wartości gruntu. W sytuacji, gdy przedmiotem umowy było wybudowanie przez użytkownika domu jednorodzinnego, dom ten stanowił własność użytkownika, jednak własność ta była prawem związanym z użytkowaniem gruntu.

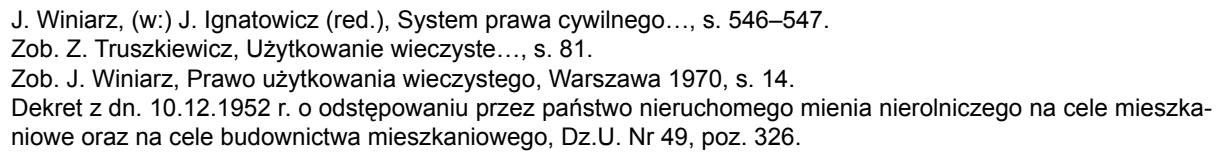


Instytucja użytkowania ustanowiona $\mathrm{w}$ dekrecie z $1952 \mathrm{r}$. w praktyce nie znalazła szerszego zastosowania. Została uchylona ustawą z dn. 28 maja 1957 r. o sprzedaży przez Państwo domów mieszkalnych i działek budowlanych ${ }^{13}$. Ustawa powróciła do znanej z prawa rzeczowego własności czasowej, przy czym w art. 6 ust. 3 zostało wskazane, że budynki znajdujące się na gruntach sprzedanych na własność czasową stanowią odrębne nieruchomości. Zmienił się zakres przedmiotowy ustawy w porównaniu do własności czasowej ustanowionej w dekrecie prawo rzeczowe, gdyż zgodnie z art. 1 ustawy przysługujące Państwu domy mieszkalne, grunty przydomowe oraz działki budowlane mogły być sprzedawane wyłącznie osobom fizycznym lub spółdzielniom mieszkaniowym.

Ustawa została wprowadzona już w czasie prac Komisji Kodyfikacyjnej, której zadaniem było przygotowanie Kodeksu cywilnego. Podejmowana była dyskusja dotycząca ustanowienia odpowiedniej formy prawnej korzystania z gruntów państwowych, która odpowiadałaby potrzebom społeczeństwa i pozostawała w zgodności z zasadami ustroju politycznego. Podczas prac Komisji jej członkowie reprezentowali różne poglądy w tym względzie ${ }^{14}$. Istotnym jest wskazanie, że właśnie w toku prac Komisji Kodyfikacyjnej doszło do uchwalenia ustawy z dn. 14 lipca 1961 r. o gospodarce terenami w miastach i osiedlach, która wprowadziła prawo użytkowania wieczystego. Równocześnie wejście w życie ustawy z 1961 r. spowodowało, że prace Komisji Kodyfikacyjnej w tym zakresie ograniczyły się do rozważania zagadnienia, który akt prawny czy Kodeks cywilny, czy może ustawa szczególna powinien regulować użytkowanie wieczyste ${ }^{15}$. Ostatecznie przyjęto rozwiązanie krytykowane od strony konstrukcyjnej, gdyż instytucja jest regulowana w obu aktach o charakterze ogólnym i szczególnym, przy czym w Kodeksie znajdują się przepisy określające trzon instytucji użytkowania wieczystego, natomiast ustawa obejmuje swym zakresem tryb oddawania nieruchomości w użytkowanie wieczyste i kompetencje organów.

\section{Cele i funkcje użytkowania wieczystego w ustawie o gospodarce terenami w miastach i osiedlach oraz w Kodeksie cywilnym}

Na podstawie ustawy z $1961 \mathrm{r}$. zostały przekształcone wszystkie istniejące wcześniejsze formy korzystania z nieruchomości państwowych w prawo użytkowania wieczystego. Wymaga podkreślenia wspólny cel instytucji poprzedzających prawo użytkowania wieczystego, który zarazem jest także celem omawianego prawa,

Dz.U. Nr 31, poz. 132

Zob. J. Winiarz, Prawo użytkowania wieczystego..., s. 17-18.

J. Majorowicz, Kodeks cywilny. Komentarz, t. I, Warszawa 1972, s. 638. 
a mianowicie utworzenie odpowiedniej instytucji, na podstawie której wskazane, ściśle określone podmioty mogły korzystać w sposób długotrwały z gruntów państwowych, w tym także zabudowując je, aby zaspokajać potrzeby mieszkaniowe. To właśnie zaspokajanie potrzeb mieszkaniowych stanowiło główną funkcję prawa użytkowania wieczystego. W doktrynie podkreśla się, że prawo to zrodziło się z potrzeb urbanizacyjnych, pierwotnie stanowiło formę wyposażenia inwestorów w konieczny zasób gruntów o przeznaczeniu budowlanym ${ }^{16}$.

W porównaniu do poprzednich regulacji użytkowanie wieczyste pozostawało w pełni zgodne z zasadami ustroju socjalistycznego, w tym zasadą jednolitości własności państwowej. Właścicielem gruntu pozostawało Państwo, zaś użytkownik otrzymywał prawo zbliżone swoją treścią do prawa własności, które podlegało dziedziczeniu oraz zbyciu.

Zgodnie $\mathrm{z}$ art. 3 ustawy o gospodarce terenami w miastach i osiedlach prawo użytkowania wieczystego terenu państwowego mogło zostać ustanowione na rzecz osób fizycznych oraz spółdzielni budownictwa mieszkaniowego. Zatem pierwotnym celem i funkcją było zaspokajanie potrzeb mieszkaniowych osób, które posiadały środki finansowe na wzniesienie budynku na gruncie lub zakup lokalu spółdzielczego. W literaturze stwierdza się, że prawo to zostało stworzone na potrzeby sektora prywatnego, gdyż jednostkom państwowym oraz organizacjom społecznym ${ }^{17}$ tereny państwowe były oddawane $\mathrm{w}$ użytkowanie ${ }^{18}$. W rozumieniu ustawy terenem państwowym był teren stanowiący własność państwa, położony w granicach administracyjnych miast i osiedli oraz położony poza tymi granicami, które zostały włączone do planu zagospodarowania przestrzennego miasta (osiedla) i przekazane dla realizacji zadań jego gospodarki. Ustanowienie użytkowania wieczystego było możliwe, gdy nie sprzeciwiało się celom ustalonym w planach zagospodarowania przestrzennego. Użytkowanie wieczyste ściśle związano z terenami miejskimi, co również wzmacniało pierwotny cel instytucji.

Sposób korzystania z terenu państwowego przez użytkownika wieczystego był ustalony w umowie ustanawiającej użytkowanie, zawieranej w formie aktu notarialnego. W przypadku, gdy w użytkowanie wieczyste był oddawany grunt zabudowany, z użytkownikiem wieczystym była jednocześnie zawierana umowa sprzedaży budynków, znajdujących się na gruncie. Przełamywano zatem zasadę superficies

16 E. Gniewek, O przyszłości..., s. 11-12, poszczególni autorzy wskazują, że celem ustanowienia użytkowania wieczystego było zaspokajanie potrzeb mieszkaniowych, zob. A. Brzozowski, Z problematyki przekształcenia..., s. 64, B. Wierzbowski, O przydatności użytkowania wieczystego, (w:) A. Bojarska (red.) Honeste vivere...: księga pamiątkowa ku czci Profesora Władysława Bojarskiego, Toruń 2001, s. 618.

17 Na podstawie ustawy były to organizacje polityczne, związki zawodowe i organizacje spółdzielcze, z wyjątkiem spółdzielni budownictwa mieszkaniowego i rolniczych spółdzielni produkcyjnych.

18 Z. Truszkiewicz, Użytkowanie wieczyste..., s. 96. 
solo cedit. W 1969 r. ${ }^{19}$ zostało wprowadzone rozwiązanie, na podstawie którego użytkownik, jeśli nie mógł nabyć na własność znajdujących się na gruncie budynków, uiszczał opłatę roczną także za użytkowanie wieczyste budynków. Również w tym postanowieniu widoczna jest funkcja zaspokajania potrzeb mieszkaniowych bez konieczności zapłaty jednorazowej ceny odpowiadającej wartości budynków. Stanowiło to niewatpliwe ułatwienie w nabywaniu prawa użytkowania wieczystego, a także jego upowszechnienie.

Użytkowanie wieczyste mogło zostać ustanowione w celu wzniesienia na oddawanym gruncie budynków. W takiej sytuacji w umowie strony określały termin rozpoczęcia i zakończenia robót, rodzaj posadowionego budynku, obowiązek utrzymania w należytym stanie. Postanowienie, które mogło zniechęcać, w szczególności osoby fizyczne do budowania budynków na gruntach pozostających w użytkowaniu wieczystym, a w konsekwencji wpływać na osłabienie podstawowej funkcji użytkowania, było zawarte w art. 21 ustawy. Przepis ten określał sposób wynagrodzenia za wzniesione przez użytkownika budynki przy rozwiązywaniu i wygaśnięciu użytkowania wieczystego. Przede wszystkim powinno to być określone w umowie między stronami: użytkownikiem a prezydium powiatowej (miejskiej, dzielnicowej) rady narodowej. W braku umownego ustalenia tej kwestii użytkownik otrzymywał wynagrodzenie w wysokości jednej czwartej części wartości budynków i innych urządzeń istniejących na terenie w dniu wygaśnięcia wieczystego użytkowania. Uwzględniając, że użytkowanie wieczyste było ustanawiane na podstawie decyzji organu gospodarki komunalnej i mieszkaniowej, to przyszły użytkownik miał niewielki wpływ na kształtowanie poszczególnych postanowień umowy, w tym na wysokość wynagrodzenia za wzniesione na gruncie budynki, a brak postanowienia umownego był równoznaczny z obowiązywaniem art. 21 ustawy. Jednak trzeba też zauważyć, że pod względem finansowym użytkowanie wieczyste było i pozostaje nadal atrakcyjną formą korzystania z gruntów w celach zabudowy ze względu na konieczność uiszczania jedynie określonego procentu wartości nieruchomości, jaką musiałby zapłacić nabywca przy zawieraniu umowy sprzedaży. Powoduje to, że osoby, których ze względów finansowych nie było stać na zakupienie gruntu i wybudowanie budynku, chętnie korzystały z prawa użytkowania wieczystego. W dłuższej perspektywie (ustanowienie użytkowania wieczystego następowało na 99 lat z możliwością dalszego przedłużenia) określenie wynagrodzenia na poziomie niższym niż wartość budynku przy uwzględnieniu jedynie procentowego udziału wartości gruntu przy ustanawianiu prawa oraz stworzenie bardzo szerokich możliwości korzystania z gruntu (na wzór prawa własności) mogło w praktyce nie stanowić okoliczności przemawiających za rezygnacją z ustanowienia prawa użytkowania wieczystego. poz. 80 . 
Wejście w życie Kodeksu cywilnego oznaczało rozszerzenie możliwości ustanawiania użytkowania wieczystego poza grunty wskazane w art. 3 ustawy z $1961 \mathrm{r}$. Przepis art. $232 \S 1 \mathrm{kc}$. stanowił niemalże powtórzenie uregulowania zawartego w ustawie, natomiast w $\S 2$ zostało zawarte stwierdzenie, że przedmiotem użytkowania wieczystego mogą być także inne grunty państwowe w przypadkach przewidzianych w przepisach szczególnych. W literaturze zaznacza się, że spowodowało to wykorzystanie użytkowania wieczystego w praktyce, ponieważ umożliwiło rozszerzenie zakresu przedmiotowego prawa w przyszłości ${ }^{20}$. Analizując zakres podmiotowy, Kodeks cywilny stwierdzał, że użytkowanie wieczyste mogło być ustanowione oprócz osób fizycznych oraz spółdzielni budownictwa mieszkaniowego także na rzecz osób prawnych określonych w przepisach szczególnych. Zatem postanowienia Kodeksu cywilnego nie były samodzielne w tej materii. Osobami prawnymi, poza spółdzielniami budownictwa mieszkaniowego, mogły być również, stosując ustawę z 1961 r., osoby prawne niebędące jednostkami państwowymi i jednostkami społecznymi.

Ustawa o gospodarce terenami w miastach i osiedlach była kilkakrotnie nowelizowana. Wprowadzane zmiany powodowały ponowne rozszerzanie zakresu zastosowania instytucji użytkowania wieczystego. Od 1969 r. użytkowanie wieczyste mogło zostać ustanowione także na gruntach zabudowanych domami jednorodzinnymi, małymi domami mieszkalnymi, domami wielomieszkaniowymi, budynkami mieszkalno-pensjonatowymi, budynkami przeznaczonymi na pomieszczenia warsztatów rzemieślniczych lub drobnych zakładów przemysłowych, zatrudniających na jednej zmianie nie więcej niż dziesięciu pracowników w produkcji oraz budynkami związanymi z gospodarstwem rolnym. Dopuszczenie możliwości ustanowienie użytkowania wieczystego na gruncie zabudowanym budynkiem o przeznaczeniu na warsztat rzemieślniczy oznaczało w szczególności przełamanie zasady powiązania omawianego prawa z budownictwem mieszkaniowym. Co więcej, można postawić tezę, że nastąpiło ostrożne powiązanie użytkowania wieczystego z funkcją wspierania przez państwo drobnej przedsiębiorczości. Istotne jest również to, że mimo iż w art. 1 ustawy było wskazane, że użytkowanie wieczyste może być ustanowione na gruntach położonych w granicach administracyjnych miast oraz poza granicami miasta, ale na gruntach włączonych do realizacji zadań jego gospodarki, to dopuszczono możliwość ustanowienia użytkowania wieczystego gruntów zabudowanych budynkami związanymi z gospodarstwem rolnym. Zatem użytkowanie wieczyste już po kilku latach od wprowadzenia do polskiego systemu prawnego zaczęło przekształcać się w prawo, którego zastosowanie było szersze niż tylko zamierzone pierwotnie wspieranie budownictwa spółdzielczego oraz indywidualnego. W literaturze są stawiane tezy, że użytkowanie wieczyste w ustawie o gospodarce terenami 
w miastach i osiedlach nie musiało być ustanawiane w celu realizacji inwestycji budowlanej. Wniosek taki wynika z art. 13 ust. 3 ustawy, który stanowił o możliwości ustanowienia użytkowania wieczystego na gruncie będącym gospodarstwem rolnym. Wszelkie zaś ograniczenia wynikały z ustaw szczególnych i zawartych tam ograniczeń dotyczących prowadzenia określonej działalności ${ }^{21}$.

\section{Prawo użytkowania wieczystego w ustawie o gospodarce gruntami i wywłaszczeniu nieruchomości}

W przyjętej kolejnej regulacji obejmującej prawo użytkowania wieczystego ${ }^{22}$ zakres podmiotowy został określony podobnie jak w poprzednio obowiązującym stanie prawnym. W przepisie art. 4 ustawy o gospodarce gruntami i wywłaszczeniu nieruchomości stwierdzono, że grunty państwowe mogą być oddane w użytkowanie wieczyste na rzecz spółdzielni mieszkaniowych, osób fizycznych, osób prawnych innych niż organizacje społeczne i państwowe jednostki organizacyjne. Również organizacje międzynarodowe i na zasadzie wzajemności obce przedstawicielstwa dyplomatyczne lub urzędy konsularne oraz inne przedstawicielstwa zagraniczne mogły uzyskać prawo użytkowania wieczystego gruntu. Ustawodawca w dalszej części ustawy doprecyzował, że przypadku osób prawnych (także spółdzielni mieszkaniowych) koniecznym wymogiem jest, aby przekazane grunty państwowe były przeznaczone do realizacji ich zadań ustawowych lub statutowych oraz służyły do zaspokojenia ich potrzeb. Można uznać, że podjęta została próba ograniczenia zastosowania instytucji poprzez ścisłe ustawowe określenie, że grunt może być oddany w użytkowanie wieczyste wyłącznie w celach statutowych, ustawowych lub zaspokojenia potrzeb osoby prawnej. Nie było zatem dowolności w przeznaczaniu przez podmioty, na rzecz których oddano grunt w użytkowanie wieczyste na jakikolwiek wybrany przez osobę prawną cel. W porównaniu do poprzedniej regulacji przyjętej na gruncie ustawy z 1961 r. różnica jest wyraźna, gdyż wówczas ustawodawca stwierdzał jedynie, że grunt może być przekazany w użytkowanie wieczyste spółdzielni budownictwa mieszkaniowego.

W ustawie z 1985 r. przy gruntach oddawanych w użytkowanie wieczyste na rzecz osób fizycznych niemal powtórzone zostało uregulowanie zawarte w zmienionym w 1969 r. art. 14. Wprowadzona zmiana ponownie zmierzała do ostrożnego poszerzania prawa użytkowania wieczystego, gdyż oprócz m.in. oddawania działki pod budowę domu jednorodzinnego osoba fizyczna mogła otrzymać grunt, a następnie zabudować go domem letniskowym, budynkiem przeznaczonym na pomieszczenia do prowadzenia działalności handlowej, usługowej i innej działalności z zakre- 
su drobnej wytwórczości, a także pracowni do prowadzenia działalności twórczej ${ }^{23}$. Dodatkowo w art. 25 zostało wprowadzone nieznane dotychczas rozwiązanie dopuszczające oddanie w użytkowanie wieczyste osobie fizycznej obiektu zabytkowego wymagającego remontu. W umowie wówczas był nakładany obowiązek odbudowy, wyremontowania i utrzymywania tego budynku w należytym stanie. Wydaje się uzasadnione twierdzenie, że w coraz większym stopniu następowało poszerzanie zastosowania i wykorzystania prawa użytkowania wieczystego na inne cele niż sama funkcja przekazywania gruntów państwowych pod zabudowę mieszkaniową, a więc zaspokajania potrzeb mieszkaniowych. Jednak nadal użytkowanie wieczyste jest powiązane z funkcją i celem zabudowy gruntu. Uwagę zwraca, podobnie jak przy poprzedniej regulacji z 1961 r., możliwość budowy na gruncie przekazanym w użytkowanie wieczyste budynków związanych z prowadzeniem gospodarstwa rolnego. Trzeba zauważyć, że prawo to miało być związane z terenami miejskimi, art. $232 \S 2 \mathrm{kc}$. dopuszczał ustanawianie prawa na innych terenach niż położone w granicach administracyjnych miast i osiedli, włączone do planów zagospodarowania przestrzennego. Jednak w przepisach szczególnych zamieszczone było postanowienie, że grunt oddany w użytkowanie może być zabudowany przez osobę fizyczną budynkami niezbędnymi do prowadzenia działalności rolniczej. Można stwierdzić, że w ten sposób użytkowanie wieczyste nie było związane wyłącznie z gruntami miejskimi.

\section{Wpływ przekształceń ustrojowych na cele i funkcje użytkowania wieczystego}

Decydujący wpływ na rozwój oraz zmianę celów i funkcji instytucji użytkowania wieczystego miała zmiana ustroju społeczno-gospodarczego. Należy pamiętać, że prawo to miało rodowód socjalistyczny i z tego względu uzasadnione mogły być głosy o potrzebie usunięcia z systemu prawnego omawianej instytucji. Jednak ustawodawca nie tylko jej nie uchylił, ale rozszerzył zakres zastosowania ${ }^{24}$.

Wraz ze zmianą ustroju został uchylony przepis art. 128 kc. dotyczący ogólnonarodowej własności socjalistycznej. Na tej podstawie własność gruntów przysługiwała niepodzielnie państwu. Uchylenie przepisów dotyczących szczególnej własności państwowej stworzyło możliwość nabywania przez państwowe osoby prawne prawa własności nieruchomości. Jednakże konieczna była również ingerencja ustawodawcy w przepisy regulujące bezpośrednio użytkowanie wieczyste. Ustawłaszczeniu nieruchomości, Dz.U. Nr 24, poz. 170.

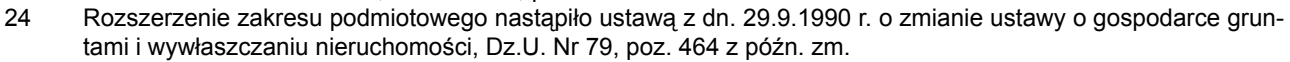


wa z 28 lipca 1990 r. ${ }^{25}$ wprowadzała bardzo istotną zmianę w art. $232 \mathrm{kc}$., usunięto ograniczenia podmiotowe. Użytkowanie wieczyste mogło zostać ustanowione na rzecz osób fizycznych, a także bez żadnych ograniczeń na rzecz osób prawnych, w tym państwowych osób prawnych. Jednak ta zmiana w praktyce nie spowodowała rzeczywistej możliwości oddawania osobom prawnym gruntów w użytkowanie wieczyste. Niezbędna była także modyfikacja przepisów ustawy o gospodarce terenami w miastach i osiedlach ${ }^{26}$ jako ustawy szczegółowej.

Przekształcenia ustrojowe doprowadziły również do przywrócenia w Polsce samorządu terytorialnego ${ }^{27}$. Gminy nabyły część własności nieruchomości stanowiących wcześniej nieruchomości państwowe. Jednak dopiero od momentu wejścia w życie przepisów zmieniających ustawę z 1985 r. z dniem 5 grudnia 1990 r. gminy mogły oddawać swoje grunty w użytkowanie wieczyste. Od dnia 1 stycznia $1999 \mathrm{r}^{28}$ także powiaty i województwa mogły oddawać grunty stanowiące ich własność w użytkowanie wieczyste.

W nowym stanie prawnym jednostki samorządu terytorialnego mogły stać się użytkownikami wieczystymi gruntu, którego właścicielem był Skarb Państwa. W zmienionym art. $232 \S 1 \mathrm{kc}$. ustawodawca nie skreślił jednak ograniczenia mówiącego o tym, że w użytkowanie wieczyste mogą zostać oddane grunty stanowiące własność Skarbu Państwa położone w granicach administracyjnych miast położone poza tymi granicami, lecz włączone do planu zagospodarowania przestrzennego miasta i przekazane do realizacji zadań jego gospodarki. Ograniczenie dotyczy tylko gruntów Skarbu Państwa, natomiast nie odnosi się do nieruchomości, których właścicielem jest jednostka samorządu terytorialnego. Taką niekonsekwencję oraz niespójność (ponieważ już wcześniej została dopuszczona możliwość przekazywania gruntów pod zabudowę budynkami mieszkalnymi i gospodarczymi niezbędnymi do prowadzenia gospodarstwa rolnego) można tłumaczyć pomyłką legislacyjną, która jednak dla czystości konstrukcji powinna być usunięta. Można zauważyć, że zapis pod względem praktycznym nie ma istotnego znaczenia, gdyż w $\S 2$ jest stwierdzone, że także inne grunty mogą być przedmiotem użytkowania wieczystego w wypadkach przewidzianych w przepisach szczególnych.

Zmiany ustroju społeczno-gospodarczego spowodowały konieczność uchwalenia nowej ustawy, która kompleksowo regulowałaby zagadnienia gospodarowania

Ustawa o zmianie ustawy Kodeks cywilny, Dz.U. Nr 55, poz. 321

Ustawa z dn. 29.9.1990 r. o zmianie ustawy o gospodarce gruntami i wywłaszczeniu nieruchomości, Dz.U. Nr 79, poz. 464 z późn. zm.

Ustawa $z$ dn. 10.5.1990 r., przepisy wprowadzające ustawę o samorządzie terytorialnym i ustawę o pracownikach samorządowych, Dz.U. Nr 32, poz.191 z późn. zm.

Ustawa z dn. 24.7.1998 r. o wejściu w życie ustawy o samorządzie powiatowym, ustawy o samorządzie województwa oraz ustawy o administracji rządowej w województwie, Dz.U. Nr 99, poz. 631 oraz ustawa z dn. 13.10.1998 r., przepisy wprowadzające ustawy reformujące administrację publiczna, Dz.U. Nr 133, poz. 872 ze zm. 
nieruchomościami. Ustawa o gospodarce gruntami i wywłaszczaniu nieruchomości została zastąpiona ustawą z 21 sierpnia 1997 r. o gospodarce nieruchomościa$\mathrm{mi}^{29}$. Analizując zakres przedmiotowy i podmiotowy ustawy, obecnie w użytkowanie wieczyste może być oddany grunt stanowiący własność Skarbu Państwa oraz jednostki samorządu terytorialnego, o dowolnym przeznaczeniu w planach zagospodarowania przestrzennego ${ }^{30}$. Natomiast istotne jest, że ustawodawca zrezygnował ze wskazania, na rzecz jakich podmiotów może to prawo zostać ustanowio$n^{31}$. Zatem można wnioskować, że użytkownikiem wieczystym może być osoba fizyczna, osoba prawna, państwowa osoba prawna, ułomna osoba prawna ${ }^{32}$. Skarb Państwa jako właściciel nieruchomości może ustanowić prawo na rzecz określonej jednostki samorządu terytorialnego, podobnie jednostki samorządu terytorialnego mogą oddawać grunty stanowiące ich własność na rzecz pozostałych jednostek. Brak ograniczeń podmiotowych w art. 13 ustawy stanowi przykład na rozszerzanie zastosowania instytucji oraz pośrednio na zwiększenie celów i funkcji spełnianych przez użytkowanie. Przez określenie, że użytkownikiem może być konkretnie wskazany podmiot - spółdzielnia budownictwa mieszkaniowego - następowało ograniczenie zastosowania instytucji użytkowania do celów zabudowy.

Prawo użytkowania wieczystego nie jest dziś ściśle związane z celem i funkcją szeroko rozumianej zabudowy gruntu. Taki obowiązek użytkownika nie został określany w ustawie. Przepis art. 62 ustawy z 1997 r. stwierdza, że strony w umowie ustalają sposób i termin jej zagospodarowania, w tym termin zabudowy, zgodnie z celem, na który nieruchomość gruntowa została oddana w użytkowanie wieczyste. Postanowienie to stwarza możliwość do znacznie szerszego wykorzystywania w praktyce prawa użytkowania wieczystego. Strony w umowie mogą wskazać na dowolny cel przeznaczenia gruntów, są jedynie związane ograniczeniami wynikającymi z zasady swobody umów. Zabudowa nieruchomości, w szczególności budynkami mieszkalnymi, stanowi według obecnych postanowień jeden z celów, na jaki może być przeznaczony grunt oddany w użytkowanie, ale nie jedyny i wyłączny. To właśnie brak ograniczeń w obowiązujących przepisach sprawia, że użytkowanie wieczyste może być wykorzystywane na szeroką skalę, nie powiązaną z budownictwem. E. Gniewek wskazuje, że z racji usunięcia ograniczeń zakresu instytucji, występuje możliwość ,przedmiotowej ekspansji” prawa użytkowania wieczyste-

\footnotetext{
29 Dz.U. Nr 115, poz. 741, teksty jednolite: Dz.U. z 2000 r. Nr 46, poz. 543, Dz.U. z 2004 r. Nr 261, poz. 2603.

30 Zob. wyrok NSA w Warszawie z dn. 28.9.2000 r., I SA 1398/99, LEX nr 57194, wyrok SN z dn. 18.7.2000 r., IV CK 67/00, LEX nr 520023.

31 Zob. wyrok WSA w Olsztynie z dn. 18.9.2008 r., I SA/OI 327/08, LEX nr 449963, w którym Sąd stwierdził, że państwowa i samorządowa jednostka organizacyjna nieposiadająca osobowości prawnej działająca na podstawie ustawy o finansach publicznych nie mogą być użytkownikami wieczystymi gruntu.

32 Użytkownikiem wieczystym może być wspólnota mieszkaniowa. Co do wątpliwości w zakresie podmiotowości prawnej wspólnot mieszkaniowych zob. P. Bielski, Zdolność prawna wspólnoty mieszkaniowej - problem modelu regulacji prawnej, „Rejent” 2007, nr 3, s. 32; G. Gorczyński, Wspólnota mieszkaniowa jako „, jednostka organizacyjna” w rozumieniu art. $33^{1} \S 1$ Kc., „Rejent” 2009 , nr 2, s. 32 i nast.
} 
$\mathrm{go}^{33}$. W innej swojej wypowiedzi Autor stwierdza, że należy ocenić jego rzeczywistą treść i przydatną funkcję społeczno-gospodarczą. Zaznacza, że użytkowanie wieczyste jest w praktyce wykorzystywane i stanowi formę taniego, długotrwałego korzystania z gruntu. Przy ustanawianiu użytkowania wieczystego nabywca nie ponosi jednorazowo pełnych kosztów nabycia nieruchomości, natomiast właściciel co roku uzyskuje wpływy do budżetu oraz dodatkowo zachowuje nadzór zgodnego z przeznaczeniem wykorzystania nieruchomości ${ }^{34}$. W dalszym ciagu instytucja ta może doskonale pełnić funkcję zabudowy gruntu, w szczególności w budownictwie mieszkaniowym, jednak tu trzeba zaznaczyć dwie kwestie. Z jednej strony oddanie gruntu w użytkowanie wieczyste pod budowę budynków wielomieszkaniowych sprawia, że cena sprzedaży lokali w budynkach może być niższa niż w przypadku prawa własności gruntu, co może zachęcać do nabycia własności lokalu mieszkalnego, znajdującego się w budynku posadowionym na gruncie oddanym w wieczyste użytkowanie. Z drugiej zaś strony należy zauważyć, że koszty utrzymania lokalu mogą być wyższe z racji ponoszenia obowiązkowych opłat rocznych z tytułu użytkowania wieczystego ${ }^{35}$.

Wydaje się, że prawo użytkowania wieczystego może znaleźć zastosowanie także w innych obszarach oraz spełniać inne funkcje niż te przypisywane tradycyjnie. W szczególności funkcją i celem omawianej instytucji może być wspieranie przedsiębiorców, pomoc państwa przedsiębiorcom. Właściciel nieruchomości: Skarb Państwa lub jednostka samorządu terytorialnego może ustanowić na rzecz przedsiębiorcy, będącego osobą fizyczną, osobą prawną czy ułomną osobą prawną prawo użytkowania wieczystego. Podobnie jak przy użytkowaniu na cele budownictwa mieszkalnego również w tym wypadku atutem jest ograniczenie kosztów rozpoczęcia prowadzenia działalności gospodarczej, gdyż nie trzeba uiszczać całej ceny za przeniesienie własności nieruchomości.

Przepis art. 10 ustawy dnia 20 grudnia 1996 r. o gospodarce komunalnej ${ }^{36}$ zezwala gminie na tworzenie i przystępowanie do spółek prawa handlowego poza sferą użyteczności publicznej. Na podstawie tego postanowienia gmina może wnieść jako aport do spółki składnik mienia komunalnego, gdy inne jego zastosowanie przyniesie gminie niepowetowane straty. Przepis ten zezwala na ustanowienie prawa użytkowania wieczystego na rzecz spółki i taki udział gminy w spółce, pod warunkiem spełniania przesłanek z art. 10 ustawy. Również w tym przypadku celem przypisywanym użytkowaniu wieczystemu może być wspieranie przedsiębiorców.

Jednak w praktyce okazuje się, że prawo użytkowania wieczystego w rzeczywistości zostało bardzo zniekształcone i przestało spełniać funkcję wspierania taniego

E. Gniewek, O przyszłości użytkowania wieczystego, „Rejent” 1999, nr 2, s. 12-13.

E. Gniewek, O przyszłości użytkowania wieczystego - dyskusji ciag dalszy, „Studia luridica Agraria”..., s. 53

Zob. jednak krytyczną wypowiedź A. Brzozowskiego, Z problematyki przekształcenia..., s. 69-70.

Dz.U. z 1997 r. Nr 9, poz. 43. 
budownictwa. Obecnie bardzo często zdarza się, że gminy ustalają wysokość pierwszej opłaty z tytułu użytkowania wieczystego na $25 \%$ wartości nieruchomości, natomiast opłaty roczne $1 \%$ (w przypadku nieruchomości oddawanych na inne cele niż mieszkaniowe wysokość opłaty rocznej kształtuje się na poziomie 3-4\% wartości nieruchomości). Zatem opłaty z tytułu użytkowania wieczystego mogą przewyższyć wartość nieruchomości, a użytkownik nie uzyskuje prawa własności nieruchomości. Można argumentować, że korzystniejszym rozwiązaniem w tej sytuacji będzie kredyt na zakup nieruchomości. Dodatkowo należy wspomnieć, że gminy, przekształcając lokale komunalne często jako prawo związane z prawem własności nieruchomości zamiast prawa we współwłasności gruntu, ustanawiają prawo udziału we współużytkowaniu wieczystym gruntu, na którym posadowiony jest budynek wielomieszkaniowy. To sprawia, że znacznie utrudnione jest przekształcenie tego prawa we własność, gdyż aby przekształcić prawo użytkowania wieczystego konieczne jest, aby z wnioskiem o przekształcenie wystapili wszyscy właściciele lokali mieszkalnych znajdujących się w budynku. W konsekwencji prawo użytkowania wieczystego można postrzegać jako spełniające cele przede wszystkim przynoszenia dochodu gminom.

\section{Próby uwłaszczenia użytkowników wieczystych}

Mimo praktycznego wykorzystania instytucji użytkowania wieczystego oraz istnienia dalszych możliwych perspektyw jego zastosowania w obszarach, w jakich nie było ono z powodów zakreślonych ustawowo wcześniej wykorzystywane, należy wskazać na podejmowane próby przekształcenia prawa użytkowania wieczystego w prawo własności, a tym samym eliminacji go z systemu prawnego lub zastapienia inną instytucją. Uzasadniona jest teza, że zamierzeniem ustawodawcy jest, aby prawo użytkowania wieczystego zostało przekształcone lub usunięte z porządku prawnego. Przede wszystkim należy wskazać na kolejne regulacje, których celem jest przekształcenie prawa użytkowania wieczystego w prawo własności. Na podstawie ustawy z dnia 4 września 1997 r. o przekształceniu prawa użytkowania wieczystego przysługującego osobom fizycznym w prawo własności ${ }^{37}$, wyłącznie osoby fizyczne mogły ubiegać się o przekształcenie przysługującego im prawa w prawo własności. W pierwotnej wersji ustawy stwierdzono, że uprawnionymi były te osoby fizyczne, które nabyły prawo użytkowania wieczystego przed dniem ogłoszenia ustawy o przekształceniu oraz osoby fizyczne, którym przysługuje prawo zabudowy nieruchomości ustanowione przed dniem wejścia w życie dekretu z dnia 26 października 1945 r. o prawie zabudowy ${ }^{38}$. W obu przypadkach prawo przysługiwało, 
jeśli uprawnieni złożyli wniosek o przekształcenie do 31 grudnia 2000 r. Wspomniana ustawa nie była i nie jest jedyną próbą zachęcenia podmiotów, którym przysługuje prawo użytkowania wieczystego do jego przekształcenia w prawo własności. Ustawa z dnia 26 lipca 2001 r. o nabywaniu przez użytkowników wieczystych prawa własności nieruchomości ${ }^{39}$ również dawała możliwość przekształcenia prawa wyłącznie osobom fizycznym ${ }^{40}$. Nie obowiązywała na terenie całego państwa, a wyłącznie na obszarze Ziem Odzyskanych i Wolnego Miasta Gdańska. Co ważne, ustawa nie określała odpłatności za przekształcenie prawa i zostało przyjęte, że odbywa się to bezpłatnie ${ }^{41}$.

Ustawa z dn. 29 lipca 2005 r. o przekształceniu prawa użytkowania wieczystego w prawo własności nieruchomości uchyliła poprzednio obowiązujące regulacje. Trzeba wspomnieć, że mimo słusznego zamysłu ustawodawcy co do propozycji przekształcenia prawa użytkowania wieczystego w prawo własności poszczególne przepisy poprzednio obowiązujących ustaw były niezgodne z Konstytucją ${ }^{42}$.

Obecnie obowiązująca ustawa rozszerzyła zakres podmiotów uprawnionych do ubiegania się o przekształcenie przysługującego im prawa. Oprócz osób fizycznych będących w dniu wejścia w życie ustawy użytkownikami wieczystymi nieruchomości zabudowanych na cele mieszkaniowe lub zabudowanych garażami albo przeznaczonych pod tego rodzaju zabudowę oraz nieruchomości rolnych, a także osób fizycznych i osób prawnych będących właścicielami lokali, których udział w nieruchomości wspólnej obejmuje prawo użytkowania wieczystego, prawo do ubiegania się o przekształcenie uzyskały spółdzielnie mieszkaniowe, będące właścicielami budynków mieszkalnych lub garaży. Zatem w określonych przypadkach również osoby prawne (a na podst. art. $33^{1} \mathrm{kc}$. także ułomne osoby prawne) mogą żądać przekształcenia w prawo własności. Podmioty uprawnione powinny złożyć wniosek do 31 grudnia 2012 r. Przekształcenie prawa jest odpłatne za wyjątkiem określonym w art. 5 ustawy.

39 Dz.U. Nr 113, poz. 1209.

40 Od 16.7.2003 r., tj. od dnia wejścia w życie ustawy z 11.4.2003 r. o kształtowaniu ustroju rolnego, Dz.U. Nr 64, poz. 592 osoby uprawnione nabywają z mocy prawa własność nieruchomości z dniem, w którym decyzja właściwego organu stała się ostateczna.

41 Zob. Z. Truszkiewicz, Użytkowanie wieczyste..., s. 113, odmiennie G. Bieniek, W sprawie przyszłości użytkowania wieczystego, (w:) Ars et usus. Księga pamiątkowa ku czci Sędziego Stanisława Rudnickiego, Warszawa 2005, s. 57.

42 Wyrok TK z dn. 12.4.2000 r., K 8/98, OTK 2000, nr 3, poz. 87, wyrok TK z dn. 18.12.2000 r., K 10/2000, OTK 2000, nr 8, poz. 298. 


\section{Instytucja własności czasowej jako propozycja zastąpienia prawa użytkowania wieczystego}

Prawo użytkowania wieczystego jest instytucją mającą swój rodowód w poprzednim ustroju społeczno-gospodarczym, charakterystycznym dla bloku państw socjalistycznych. Stwarzało możliwość zabezpieczenia potrzeb mieszkaniowych ludności oraz przede wszystkim odpowiadało podstawowej zasadzie jednolitości własności państwowej. Zatem łączyło dwie istotne i, wydawać by się mogło, niedające pogodzić się sprzeczności: pozostawanie własności nieruchomości w rękach państwa przy równoczesnym umożliwieniu sprawowania władztwa i szerokiego prawa do nieruchomości na wzór prawa własności ${ }^{43}$ przez osoby fizyczne oraz przysługującym użytkownikowi prawie zabudowy przede wszystkim budynkami mieszkalnymi. Obecnie obowiązująca ustawa o gospodarce nieruchomościami nie przewiduje żadnych ograniczeń co do możliwości wykorzystania prawa użytkowania wieczystego. To użytkownik wieczysty i właściciel nieruchomości mogą w umowie o ustanowieniu użytkowania wieczystego określić cel i funkcje, jakie w danym przypadku ma spełniać omawiana instytucja. Jednak mimo istnienia szerokich podstaw do wykorzystania instytucji, a także rzeczywistej praktycznej obecności w obrocie, zasadnym jest poddanie w wątpliwość jej dalszej obecności w polskim prawie cywilnym. Poszczególni autorzy wskazują na potrzebę dostosowania polskiego prawa rzeczowego do porządków prawnych państw europejskich, w których nie istnieje prawo pośrednie między prawem własności a prawami rzeczowymi ograniczonymi w postaci użytkowania wieczystego. Zaznaczają, że jest to prawo całkowicie niezrozumiałe dla podmiotów zagranicznych. Wydaje się, że oprócz tych argumentów można zastanowić się, czy nie jest zasadnym wprowadzenie instytucji, która będzie mogła spełniać funkcje, jakie mimo braku ograniczeń w możliwych celach wypełnianych przez użytkowanie wieczyste prawo to w dalszym ciagu spełniać nie może. Przede wszystkim należy zaznaczyć, że użytkowanie wieczyste jest prawem ściśle związanym ze stosunkami miejskimi. Jakkolwiek w ustawie o gospodarowaniu nieruchomościami rolnymi Skarbu Państwa ${ }^{44}$ zostało stwierdzone, że gospodarowanie nieruchomościami rolnymi obejmuje mienie znajdujące się w użytkowaniu wieczystym osób fizycznych i prawnych, to jednak nigdy nie było możliwe oddanie w użytkowanie wieczyste gruntów rolnych. Własność czasowa może w odniesieniu do nieruchomości rolnych znaleźć zastosowanie, w tym przede wszystkim, gdy właścicie-

Zob. postanowienie SN z dn.14.1.2009 r., IV CSK 367/08, LEX nr 487531 w zakresie różnicy między posiadaniem samoistnym właściciela nieruchomości a posiadaniem samoistnym użytkownika wieczystego. 
lem czasowym byłby cudzoziemiec ${ }^{45}$. W ustawie o kształtowaniu ustroju rolnego ${ }^{46}$ zostały wprowadzone ograniczenia przy nabywaniu nieruchomości rolnych. Jednak rzeczywistą podstawą ich wprowadzenia jest zapobieganie nabywaniu nieruchomości rolnych przez cudzoziemców. Cudzoziemiec, spełniający warunki z art. 6 usta$\mathrm{wy}^{47}$, mógłby nabyć na określony czas nieruchomość, na której prowadziłby gospodarstwo rolne, a po upływie wskazanego czasu własność przeszłaby z powrotem na poprzedniego właściciela. Wykorzystanie w tym celu użytkowania wieczystego miałoby ograniczony zasięg, uniemożliwiałoby przekazanie nieruchomości, których właścicielem nie jest Skarb Państwa lub jednostka samorządu terytorialnego, czyli nastąpiłoby wyłączenie nieruchomości, których właścicielem są podmioty prywat$n e^{48}$.

Pozostałe funkcje, które obecnie spełnia użytkowanie wieczyste, mogą mieć zastosowanie także przy własności czasowej (wspieranie budownictwa, przedsiębiorczości).

Komisja Kodyfikacyjna Prawa Cywilnego w Zielonej Księdze opowiada się za eliminacją z przyszłego kodeksu cywilnego użytkowania wieczystego i zastapienia go prawem zabudowy jako nowym typem ograniczonego prawa zabudowy, które przejmie dotychczasowe funkcje spełniane przez użytkowanie wieczyste. Komisja zaznacza, że obecnie użytkowanie wieczyste nie odpowiada wymaganiom systemowym stawianym przez konstytucję prawom rzeczowym. Stwierdza, że sama geneza prawa użytkowania wieczystego nie uzasadnia jej eliminacji z systemu prawnego, ale wykazuje wady konstrukcyjne i legislacyjne ${ }^{49}$. Dodatkowo w doktrynie i orzecznictwie wskazuje się na niejasny charakter prawny użytkowania wieczystego ${ }^{50}$.

Wydaje się, że w przyszłym kodeksie cywilnym prawo użytkowania wieczystego powinno zostać „zastapione” inną instytucją, znaną podmiotom państw członkowskich Unii Europejskiej i zharmonizowaną z prawem unijnym. Można postu-

W doktrynie są zgłaszane propozycje, aby rozciąnąć konstrukcje użytkowania wieczystego także na grunty rolne, zob. Z. Gawlik, Użytkowanie wieczyste de lege ferenda, (w:) M. Sawczuk (red.), Czterdzieści lat..., s. 121 i lit. tam powołana; G. Bieniek, (w:) G. Bieniek i in., Komentarz do ustawy o gospodarce nieruchomościami, t. I, Zielona Góra 2000, s. 120, zob. też wcześniejszą wypowiedź S. Breyera, Zagadnienia cywilno-prawne dotyczące nieruchomości rolnych na obszarze miast i osiedli, SP 1969, nr 23, s. 79. Ustawa z dn. 11.4.2003 r., Dz.U. Nr 64, poz. 592.

47 Możliwe byłoby odstapienie od wymogu zamieszkiwania w gminie, w której jest położona jedna z nieruchomości rolnej wchodzących w skład gospodarstwa.

48 Zwolennicy utrzymania prawa użytkowania wieczystego proponują rozszerzenie tego prawa na nieruchomości stanowiące własność osób fizycznych, $\mathrm{H}$. Cioch, Prawo użytkowania wieczystego de lege lata i de lege ferenda, „Rejent” 2003, nr 3, s. 15; B. Wierzbowski, O przydatności..., (w:) A. Bojarska (red.) Honeste vivere..., s. 624.

49 Zielona Księga. Optymalna wersja kodeksu cywilnego w Rzeczypospolitej Polskiej, Z. Radwański (red.), Warszawa 2006, s. 69 i nast.

50 Zob. A. Stelmachowski, Zarys teorii prawa cywilnego, Warszawa 1998, s. 178-179; W. Pańko, O prawie własności i jego współczesnych funkcjach, Katowice 1984, s. 108 i nast.; G. Bieniek, W sprawie przyszłości..., s. 61; uzasadnienie uchwał SN: $z$ dn. 22.10.1968 r., III CZP 98/68, OSNC 1969, nr 11, poz. 188; z dn. 9.12.1969 r., III CZP 85/69, OSNC 1970, nr 10, poz. 172; wyrok SN z dn. 25.6.1998 r., III CKN 566/97, OSNC 1999, nr 1, poz. 17; wyrok WSA w Krakowie z dn. 27.12.2007 r., II SA/Kr 1306/06, LEX nr 480121; wyrok NSA w Warszawie z dn. 25.8.1998 r., IV SA 1363/96, LEX nr 45909. 
lować, aby do prawa polskiego została ponownie wprowadzona własność czasowa według rozwiązań przyjętych w dekrecie z 1946 r. prawo rzeczowe. Ważnym jest również, by nie ograniczać zakresu podmiotowego i przedmiotowego nowej instytucji oraz enumeratywnie nie wskazywać, na jakie cele może być wykorzystywana oddana we własność czasową nieruchomość. Takie rozwiązanie sprawi, że nowa instytucja będzie mogła być wykorzystywana w celu zaspokajania potrzeb mieszkaniowych, celach rolnych, jak też pozwoli pozyskać nieruchomości do prowadzenia działalności gospodarczej. Zasadnym jest również twierdzenie, że możliwość ustanawiania własności czasowej zarówno na nieruchomościach stanowiących własność Skarbu Państwa, jednostek samorządu terytorialnego, jak też osób fizycznych ożywi i ułatwi obrót gospodarczy. 


\title{
EFFECT OF TIME ON THE OBJECTIVES AND FUNCTIONS OF PERPETUAL USUFRUCT
}

\author{
SUMMARY
}

Perpetual usufruct is the law characteristic of the socialist system. In Poland, was introduced in 1961, the Law on economic grounds in the towns and settlements. Originally its function was to satisfy the housing needs, representing investors in the form of equipment necessary to allocate land resource construction. Perpetual usufruct could be established only on land which was owned by the State, and only to natural persons and housing cooperatives. Over time, with the changes in the subjective and objective transformations and functions underwent right of perpetual use. Already several years after entry into the Polish legal system perpetual usufruct began to transform into a law whose application was broader than was originally intended to support construction.

Currently, the perpetual usufruct can be established for the benefit of any natural or legal person. The owner of the land is the State Treasury or local government unit. Depending on the entity on whose behalf perpetual usufruct was established, and use of donated land for perpetual usufruct right can meet different objectives. Parties to the agreement set any aim land use cast in perpetual usufruct, are only related to the constraints of the principle of contractual freedom. This is precisely the lack of restrictions on current legislation makes perpetual usufruct can be used on a large scale, is not related to construction. Among legal scholars have pointed out that currently there is a possibility, ,the expansion of the" perpetual usufruct. However, it should also be noted attempts to transform the ownership rights, which may speak for abolition perpetual usufruct in future legislation. 